Гончар Ю.М., acn.

Київський національний торговельно-економічний університет, м. Київ, Україна

\title{
РАЦІОНАЛЬНІ ПАРАМЕТРИ ВИРОБНИЦТВА ЕМУЛЬСІЙНИХ СОУСІВ
}

Здоров'я населення, за оцінками експертів ВОО3, на 70\% залежить віл способу життя, найважливішим чинником якого є харчування. Протягом останніх років спостерігається стійке порушення структури харчування населення України. Метою державної політики в галузі харчування $\epsilon$ зміцнення i збереження здоров'я населення та профілактика захворювань. Основою для досягнення поставленої мети $є$ виробництво харчових продуктів цільового призначення з високою харчовою і біологічною цінністю. Зростаючою групою осіб, що потребують корегування раціону, є хворі на мальабсорбцію лактози. Мальабсорбція лактози - це часткова несприйнятливість до лактози, що характеризується неповним ії всмоктуванням стінками кишечника. Обмеження споживання лактози може тимчасово покращити стан хворих, проте при довгостроковому дотриманні принципів дієти, що не містить молочних продуктів, можуть виникати супутні захворювання. Обмеження споживання лактозовмісних продуктів унеможливлює споживання достатньої кількості необхідних поживних речовин, таких як кальцій, фосфор, вітамін $\mathrm{B}_{2}$ (рибофлавін) та вітамін $\mathrm{D}$ (ергокальциферол), що може призвести до зменшення щільності кісток, підвищенню крихкості, може спричинити остеопороз. Обмежуюча дієта також справляє негативний вплив на якість життя, оскільки хворі самовільно обмежують прийом не тільки молочних продуктів, але й інших харчових продуктів, що містять лактозу.

Таким чином, актуальним $є$ питання розробки інноваційних технологій харчових продуктів зі зниженим вмістом лактози цільового призначення для осіб з мальабсорбцією.

Для розв'язання цієї проблеми розроблено технологію напівфабрикату на основі низьколактозної ферментованої молочної сироватки, яку попередньо згущують, та ферментованого пюре з м'якоті гарбуза з підвищеним вмістом пектину, який попередньо диспергують [1]. Молочна складова напівфабрикату володіє відмінними емульгувальними властивостями, а овочева - структуроутворювальними, 
що обумовлює можливість використання напівфабрикату в складі емульсійних соусів.

За пропонованою інноваційною технологією емульсійний соус представляє собою двокомпонентну систему, що складається 3 олії рослинної соняшникової рафінованої дезодорованої та напівфабрикату на основі низьколактозної ферментованої молочної сироватки та диспергованого пюре з м'якоті гарбуза з підвищеним вмістом пектину. Досліджено функціонально-технологічні властивості емульсійних соусів з використанням альтернативних інгредієнтів при раціональному співвідношенні компонентів $70: 30$.

Однією з основних функціонально-технологічних властивостей емульсійних соусів $\epsilon$ їх в'язкість. Цей показник виступає в прямій залежності від температури емульгування $\left(\mathrm{t},{ }^{\circ} \mathrm{C}\right)($ рис. 1$)$.

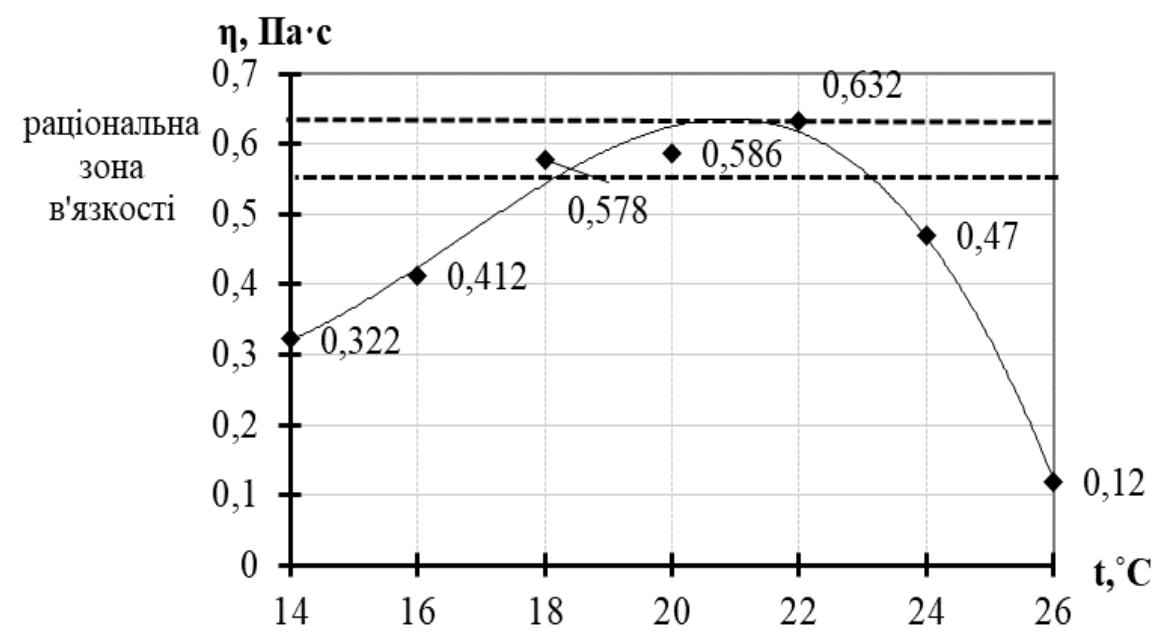

Рис. 1. Залежність в язкості соусу ( $\eta$, Па.с) від температури $\left(t,{ }^{\circ} \mathrm{C}\right)$

3 рис. 1 видно, що в'язкість полідисперсної системи за підвищення температури емульгування знижується. 3 одного боку, зниження в'язкості полегшує процес емульгування олії, а з іншого, може спричиняти агрегативну нестійкість емульсії. Раціональними значеннями в'язкості емульсійних систем, згідно ДСТУ, є 0,55-0,63 Па·с. Таким чином, раціональною температурою емульгування визначено діапазон температур від $18^{\circ} \mathrm{C}$ до $22^{\circ} \mathrm{C}$, за яких в'язкість соусу відповідає стандартним значенням.

\section{Список бібліографічних посилань}

1. Гніцевич В.А. Юдіна Т.І., Гончар Ю.М. Технологія напівфабрикату на основі низьколактозної молочної сироватки та м'якоті гарбуза. Товари і ринки. - 2018. - № 4. - С. 105-114. 